Canadian University Music Review

Revue de musique des universités canadiennes

\title{
Mark DeBellis. Music and Conceptualization. Cambridge: Cambridge University Press, 1995. viii, 163 pp. ISBN 0-521-40331-6 (hardcover)
}

\section{Harold E. Fiske}

Volume 18, numéro 2, 1998

URI : https://id.erudit.org/iderudit/1014666ar

DOI : https://doi.org/10.7202/1014666ar

Aller au sommaire du numéro

Éditeur(s)

Canadian University Music Society / Société de musique des universités canadiennes

ISSN

0710-0353 (imprimé)

2291-2436 (numérique)

Découvrir la revue

Citer ce compte rendu

Fiske, H. E. (1998). Compte rendu de [Mark DeBellis. Music and

Conceptualization. Cambridge: Cambridge University Press, 1995. viii, 163 pp. ISBN 0-521-40331-6 (hardcover)]. Canadian University Music Review / Revue de musique des universités canadiennes, 18(2), 127-132.

https://doi.org/10.7202/1014666ar

All Rights Reserved (c Canadian University Music Society / Société de musique des universités canadiennes, 1998
Ce document est protégé par la loi sur le droit d'auteur. L’utilisation des services d'Érudit (y compris la reproduction) est assujettie à sa politique d'utilisation que vous pouvez consulter en ligne.

https://apropos.erudit.org/fr/usagers/politique-dutilisation/ 
Land" by Johnnie Allan. The performances span a variety of swamp-pop styles and eras and include examples of the faster swamp-pop rockers such as "Opelousas Sostan" by Rufus Jagneaux and the slower ballad forms such as Johnnie Allan's "Lonely Days and Lonely Nights." This music, naive in its technical simplicity, nonetheless expresses a wide range of emotions and projects an indefinable, yet ineffable, rock and roll spirit. Though the recordings are, in some cases, almost forty years old they maintain a refreshing vitality - a testimony both to the original spirit of the music and the fact that it has received very little commercial exposure over the ensuing decades. The $\mathrm{CD}$ is a wonderful companion to the book and brings Bernard's writing and his case studies to life. It is both an invaluable aural introduction to, and documentation of, this nearly extinct musical genre.

Bernard's goal in writing this book is to increase the general awareness and appreciation of the genre of swamp-pop music and to voice his concerns "about whether it could survive and about how it was perceived" (p. 5). Consequently the writing contains little in the way of detailed musical or cultural analysis or criticism but a wealth of first-hand descriptions and accounts of the music and its conception. Accordingly, Bernard treats his subject with the warmth and affection of someone born into the swamp-pop tradition. Indeed the largest part of his work is drawn from the author's own interviews with the original swamp-pop artists. His message regarding the importance of this regional popular music style and its impending demise is well taken and the book provides a comprehensive survey of the genre and its artists and nicely imparts the complex flavours of the swamp-pop experience. As such it represents a unique and long overdue study of an important yet overlooked musical genre. Indeed, if only for the obvious linguistic and cultural parallels, it is a work worth reading by anyone interested in the pop music history of our own French-Canadian heritage.

Ken McLeod

Mark DeBellis. Music and Conceptualization. Cambridge: Cambridge University Press, 1995. viii, 163 pp. ISBN 0-521-40331-6 (hardcover).

Mark DeBellis's new book, Music and Conceptualization, offers a formal philosophical analysis of the following thesis: "a trained music listeners hear music differently from 'ordinary listeners." DeBellis begins with an assumption:

a trained [music] listener's perceptual concepts are typically integrated with theories of music and analytic frameworks. ... [A]n ordinary listener's musical hearing [is typically not integrated this way and therefore] is strongly nonconceptual" (p. 7, italics mine).

So, for DeBellis, "training" is the listener's ability to apply music-theoretic concepts to what s/he hears perceptually: "the semantic properties of "hears ... as a dominant' depend on those of 'is a dominant,' and our understanding of 
what it is for someone to hear a pitch as a dominant depends on a prior understanding of what it is for a pitch to be a dominant" (p. 20). The distinction between levels of musical competence, perceptually at least, is that "hearing and thought are related by epistemic (i.e., conceptual) equivalence for the trained listener, but not for the ordinary listener" (p. 28).

Right from the start DeBellis assumes that there are differences in what is heard between music listeners of varying abilities, where "abilities" are carefully marked as training in music theory. (He adds that some of this ability may be intuitive, but he does not pursue this possibility very far.) This assumption leads DeBellis to his "null hypothesis: ... that musical hearing is perceptual belief and hearing ascriptions are ascriptions of perceptual belief" (p. 26). In short, DeBellis assumes that music is a composer- or performer-structured event (more on this later). Further, that some listeners perceive these structures by means of acquired music-theoretic concepts (where a "concept" is "a certain psychological capacity ... in which one grasps a particular mode of presentation" [p. 32] - e.g., "dominant"), and that other listeners (those who are untrained in music-theoretic concepts) do not perceive these structures. Musictheoretic concepts perceived by a trained listener result in musical beliefs, where a "belief" is equivalent to holding a particular music-theoretic concept. Since, therefore (and somewhat tautologically), "trained" listeners must hold different beliefs from "untrained" listeners (who, from this viewpoint, may even hold no beliefs or at least not a belief that is unified by a single music-theoretic concept) about what they hear, "trained" listeners hear music differently from "untrained" listeners. Indeed, for DeBellis the latter group is perceptually deficient (p. 40 n. 43).

Contemporary research in music cognition is largely about pattern representation, discrimination, and concomitant beliefs as they pertain thereof. But DeBellis, in order to facilitate his argument, contends that certain kinds of musical representations are not beliefs; they are instead "strongly nonconceptual representations." DeBellis explains:

On the given model, a listener (of a certain kind), upon hearing a musical passage (of a certain kind in certain circumstances), will represent certain events in the same way. But the [ordinary] listener has no ability to discriminate those events and others; nor is he disposed to judge that those events, and only those events, are similar in any salient respect. The said representations of those events are not, in short, unified for that listener under the same concept or mode of presentation. Therefore, that kind of presentation cannot (qua type) be a perceptual belief. (pp. 61-62, italics mine)

DeBellis offers an example: "An ordinary, untrained listener ... cannot reliably tell, in general, when two pitches of [a] melody are the same-as on the italicized words in 'Oh-oh say can you see, by the dawn's early light' [opening phrase of the American National Anthem]-and when they are different. He cannot reliably discriminate between same-pitch pairs and different-pitch pairs; he is not (in general) able to grasp them as the same" (p. 62). DeBellis's point is that "Yet, on the given theory, [the ordinary listener] has type-identical 
representations of such pitches; hence, that representation (qua type) cannot be a belief and cannot involve perceptual concepts of absolute [sic] pitch locations" (pp. 62-63). There are two points here. The first is that perception of a musical event alone is not equivalent to a perceptual belief about that event; that we need a music-theoretic concept (equivalent to a perceptual belief, a benefit of training in music theory) in order to interpret (or know or discriminate) that event. Secondly, that without possessing music-theoretic concepts (i.e., without training in music theory) listeners will be unable to realize a music structural feature, even as simple as two same-pitch tones a few measures apart, despite the fact the listener holds the same type-identical representation of those pitches as the expert listener. This conclusion seems quite extraordinary. If true, how is it possible, for example, for "ordinary" listeners, including very young children, to sing or whistle back a tune previously heard with quite reasonable accuracy? How is it possible for young Suzuki students, who learn to play violin or cello by imitation without any instruction in note reading and certainly not formal music theory, to perform so impressively? Surely a cognitive concept (even an intuitive one), not merely a perceptual type-identical realization, of two-same-pitched-notes, for example, is what enables anyone, trained in theory or not, to reproduce a song more or less correctly. If so, then surely, this too is (theoretically) equivalent to a perceptual belief. Unfortunately, even though DeBellis tells us, quite rightly, that his is an empirical argument (p. 61), he offers no evidence for his conclusion. Nor does he cite relevant studies in musical pattern representation. ${ }^{1}$ To be fair, most music perception and cognition studies use only expert listeners as subjects. As far as I know, there have been no studies that address DeBellis's hypothesis in which "ordinary" listeners are compared with trained listeners. Even so, as offered by DeBellis in his theoretical model, the suggestion that ordinary listeners lack the ability to make relevant and accurate type-identical pitch discriminations-even if the suggestion is intended to be taken speculatively, which apparently it is not-seems outlandish.

How could relatively abstract music-theoretic concepts gained from training in music theory be a principal determinant of perceptual discrimination and categorization ability, i.e., music-perceptual beliefs? DeBellis explains that perceptual representation is not a belief "because a listener who enjoys that representation need not be able to discriminate between instances of [pitch differences or similarities], or scale step, and noninstances" (p. 64). By contrast, tonal ear training "is work," he says.

1 Although there are some; see, for example, Mari Riess Jones and Marilyn Boltz, "Dynamic Attending and Responses to Time," Psychological Review 96 (1989): 459-91; Mari Riess Jones, "Attending to Musical Events," in Cognitive Bases of Musical Communication, ed. Mari Riess Jones and Susan Holleran (Washington, D.C.: American Psychological Association, 1991); Carolyn Drake and Caroline Palmer, "Accent Structures in Music Performance," Music Perception 10 (1993): 343-78; Caroline Palmer and Susan Holleran, "Harmonic, Melodic, and Frequency Height Influences in the Perception of Multivoiced Music," Perception and Psychophysics 56 (1994): 301-12; Edward W. Large, Caroline Palmer, and Jordan Pollack, "Reduced Memory Representations for Music," Cognitive Science 19 (1995): 53-96; Caroline Palmer, "On the Assignment of Structure in Music Performance," Music Perception 14 (1996): 23-56. 
[I]t is not a trivial matter of learning to apply labels, but entails the development of new [read "additional"] perceptual abilities. ... [This] entails the acquisition, or the development, of perceptual concepts of particular scale step locations-the movable-do system may be especially efficacious for this - and related perceptual concepts, such as that of a perfect fifth (learning to "hear intervals" is a matter of acquiring perceptual concepts of particular intervals) (pp. 64-65).

The distinction between abstract labelling of music-theoretic concepts and their acquisition through formal ear training goes far toward satisfying my Suzuki concern. What is the Suzuki approach if not extensive practice in ear training? But it offers no help at all for explaining ordinary listeners' ability to accurately reproduce previously heard melodies (albeit, not on string instruments). "Ordinary" listeners have not had formal ear training nor have they read music theory texts, but many are still able to sing something back "by ear." Is there a measurable cognitive difference between, for example, what Suzuki students accomplish and what "ordinary" listeners can do?

DeBellis attempts to address this concern by building into his argument a set of constraints: "My point has not, however, been to argue that untrained listeners typically have no musical concepts or no perceptual beliefs in connection with music. The point is rather that one's concepts are constrained by what one can recognize" (p. 65, my italics). But DeBellis is none too clear about what he means by "constrained." Are we to take it that there is a set of constraints effectively serving as limits-to-be-overcome, such that meeting certain criteria that dissolve these constraints is equivalent to holding the prerequisite music-theoretic concepts necessary for music-perceptual belief? If so, what are the particular constraints that need to be overcome and what are the criteria for doing so? Or, does he mean that there is a continuum of constraints, the complete list of which limits the listener to perceptual realization alone, while reducing this list leads to more sophisticated and knowledgeable music-perceptual belief states? DeBellis offers little guidance here. He does suggest "that certain features [i.e., music structural features] are nonconceptual" (p. 72), but without knowing which features are conceptual and which are not, this suggestion gets us nowhere. (A few examples are scattered throughout the book, but no general law specifying this distinction is identified.) He also refutes any suggestion that constraints describe some sort of processing stage leading to perceptual belief acquisition. All he tells us is that "[s]trongly nonconceptual hearing exhibits lack of inferential integration in, among other ways, the following: for a given state of hearing (qua type), tokens of that type are not inferentially integrated with one another; for example, the representation of each of two sound-events $\mathrm{x}$ and $\mathrm{y}$ as [major thirds] (and the belief that $\mathrm{x}$ is distinct from $\mathrm{y}$ ) need not lead to the conclusion that at least two sound-events are [both major thirds]" (p. 75). So, while the recognition of "Happy Birthday" is common amongst "ordinary listeners," and while this recognition constitutes the perceptual belief of hearing "Happy Birthday," this recognition merely depends, says DeBellis, upon perceptual representations and not music-theoretic concepts. Expert listeners will still hear "Happy 
Birthday" differently from ordinary listeners. Even if we were to accept the hypothesis that music-theoretic concepts result in belief states that are different from perceptual realization alone, we are still left with the question, what is the set of distinguishing concepts and why does cognitive possession of this set cause a change in belief states?

DeBellis's argument that expert listeners hear the same musical events differently from ordinary listeners is hinged on another, more basic question, one that DeBellis himself is aware of. That question is, are music-theoretic structures contained in sound itself or are they imposed upon sound by the listener? Although the answer to this question, either way, would not change DeBellis's central claim, it does affect his interpretation of both the source of music-theoretic structures and the point at which listener-constraints enter into the perceptual-cognitive process. About halfway through reading the book it occurred to me that DeBellis could save his argument by taking advantage of Jerry Fodor's modularity theory. ${ }^{2}$

Briefly, Fodor hypothesizes a set of brain mechanisms (called modules), each of which is concerned with processing a specific kind of stimulus information to the exclusion of any other. Fodor proposes that language is controlled by one of these modules while quantitative relationships are controlled by another. Interestingly, while not a musician himself (instead he is a cognitive philosopher), Fodor proposes a similar module for music. He also hypotheses two kinds of cognitive activity, input analysis (the site for modules) and central processes, where the products of input analysis come together resulting in comparisons between these products and the perceiver's personal beliefs and experiences. (If true, this may explain how music appears to be quantifiable even while the music module is probably limited to realizing pitch-durational patterns and interrelationships.)

Attaching music-theoretic concepts to the "central processing" stage of Fodor's model seems to explain perceptual differences between listeners, and account as well for acquired music-theoretic concepts. Treating music-theoretic concepts as belief-formulated "corrections" to perceptually realized musical structures delivered as hypotheses to the central processors would account for the additional knowledge, and therefore musical-perceptual "beliefs," held by expert listeners. So it was gratifying to discover in a later chapter that DeBellis wondered the same thing. DeBellis pits his argument against two quite opposing theories of mind, one proposed by Paul Churchland and the second by Fodor. Without going into great detail here, Churchland argues that the brain is "plastic" and theory-laden, that "anything might be observed depending upon theoretical context ... [Y] ou can change your observational capacities by changing your theories." 3 Fodor, on the other hand, argues instead that perception is theory neutral, that the brain is designed to intuitively construct certain kinds of mental representations out of impacting stimuli, modifying these hypothesized constructs through beliefs that result

2 Jerry Fodor, The Modularity of Mind (Cambridge, Mass.: MIT Press, 1983).

3Fodor, A Theory of Content (Cambridge, Mass.: MIT Press, 1990). 
from learning and previous experiences. In effect, Churchland argues that we observe order in the environment according to whatever theory we impose on that environment, while Fodor argues that our percepts are brain-constructed and restricted to certain genetically-determined outcomes. Alas, after providing an interesting comparison between Churchland and Fodor, DeBellis opts for Churchland.

Rewarding as this discussion is, in my opinion DeBellis makes the wrong choice. While following Churchland might seem consistent with his own argument, the choice only gets him into a theoretical contradiction. If it is the case that music-theoretic concepts are acquired primarily through intensive ear training and formal instruction in music theory, then a music-interpretive token should both depend on that training and reflect it specifically. If so, this would account for the differences between ordinary and expert listeners that DeBellis claims is the case. But DeBellis also says that

properties detailed in theories of music [belong] to musical passages and their sounded instances. ... [M]usic perception is a matter of representing sound-events as having such properties. ... A music-perceptual state thus has a truth value: it is true or false depending on whether it represents the sounded passage as it is. (p. 109 and n. 49, italics mine)

In short, the contradiction is this: by invoking music-theoretic concepts as the cause of perceptual discrepancies, DeBellis must account for their source; leaning on Churchland, he claims that music-theoretic concepts the listener holds determines the musical structural tokens perceived; however, he also claims that musical structures are actually contained in the acoustic event itself. ${ }^{4}$ Clearly, DeBellis cannot have it both ways; realized musical structures cannot both be object-determined and mind-determined.

Treatment of theory-of-music problems by trained philosophers has been rare. ${ }^{5}$ DeBellis is a highly skilled philosopher with a strong sense of the kinds of musical issues that require appropriate treatment through philosophical analysis methodology. While I question the validity of DeBellis's conclusions and his background in music psychology, the book offers a number of new starting points for future investigations and, for perhaps many readers, a fresh approach to theories of the musical mind.

Harold E. Fiske

4 At the same time distorting, I think, Churchland's view.

5Diana Raffman's book, Language, Mind, and Music (Cambridge, Mass.: MIT Press, 1993) is one recent example that comes to mind. 